\title{
POTENSI TEH JANTUNG PISANG BATU (Musa balbisiana Colla) SEBAGAI GALAKTAGOG DALAM MENINGKATKAN KADAR PROLAKTIN SERUM SELAMA MASA LAKTASI
}

\author{
Giyawati Yulilania Okinarum ${ }^{1}$, Lestariningsih ${ }^{2}$, Afroh Fauziah ${ }^{3}$ \\ ${ }^{1,2,3}$ Fakultas Ilmu Kesehatan, Universitas Respati Yogyakarta, gitaokinarum@ @espati.ac.id
}

\section{INFORMASI ARTIKEL:}

\section{Riwayat Artikel: \\ Tanggal di Publikasi: Desember 2020}

Kata kunci:

Galaktagog

Kadar prolaktin serum

Laktasi

Teh jantung pisang batu

\section{A B S T R A K}

Kadar prolaktin yang kurang pada ibu menyusui dapat menghambat proses laktogenesis, akibatnya produksi ASI menurun hingga menjadi salah satu penyebab kegagalan pemberian ASI eksklusif. Jantung pisang batu (Musa balbisiana Colla) menjadi salah satu tanaman yang dapat meningkatkan kadar prolaktin karena adanya efek galaktagog serta kandungan flavonoid dan polifenol yang mampu memengaruhi sistem endokrin dan fungsi hormon untuk merangsang sekresi air susu. Pengembangan jantung pisang batu dalam sediaan teh yang praktis dikonsumsi dan terstandar dapat menjadi salah satu olahan alternatif guna meningkatkan kadar prolaktin serum. Tujuan penelitian ini untuk mengetahui potensi teh jantung pisang batu dalam meningkatkan kadar prolaktin serum. Sebanyak 60 responden dalam penelitian ini adalah ibu menyusui kurang dari 6 bulan di Wilayah Kabupaten Sleman dan Kota Yogyakarta. Sampel diamil secara acak dengan blok permutasi. Desain yang digunakan yaitu single blind randomized control trial pretest posttest control group. Kelompok intervensi mendapatkan teh jantung pisang batu sebanyak dua kantong teh per hari (@2,5 gram) yang harus dikonsumsi selama tujuh hari, sementara itu kelompok intervensi diberikan teh (Camellia sinensis). Kadar prolaktin serum diukur sebelum konsumsi di hari pertama dan setelah konsumsi di hari ke delapan menggunakan analisis biokimia darah VIDAS. Data dianalisis menggunakan uji Wilcoxon dan Uji Mann Whitney, karena data tidak berdistribusi normal. Terdapat perbedaan kadar prolaktin serum yang signifikan anatara kelompok intervensi dan kontrol $(\mathrm{p}<0,05)$. Ibu menyusui yang mengkonsumsi teh jantung pisang batu selama tujuh hari berturut-turut mengalami kenaikan kadar prolaktin serum sebesar 30,85\%. Teh jantung pisang batu memiliki efek galaktagog yang dapat meningkatkan kadar prolaktin serum selama masa laktasi. 


\section{PENDAHULUAN}

Permasalahan yang berkaitan dengan kekurangan nutrisi sebagai salah satu penyebab Angka Kematian Bayi (AKB) dan Angka Kematian Balita (AKABA), masih menjadi topik kesehatan utama di Indonesia. Data yang diperoleh dari Survei Demografi dan Kesehatan Indonesia (SDKI), melaporkan bahwa AKB sebesar 32 dan AKABA 40 per 1.000 kelahiran hidup (BPPSDM RI, 2012). Faktor gizi menyumbang angka kematian terbesar, yaitu sebanyak 53\% (Kemenkes RI, 2018). Sebanyak 1,4 juta kematian pada balita di dunia per tahunnya, dapat dicegah dengan pemberian Air Susu Ibu (ASI) secara optimal, hal tersebut disebabkan oleh ASI yang kaya zat gizi makro maupun mikro yang dibutuhkan bayi pada awal kehidupannya (UNICEF, 2010). Capaian pemberian ASI eksklusif di Indonesia hanya 54,3\% hal tersebut masih jauh dari target nasional sebesar $80 \%$. Persentase pemberian ASI eksklusif yang paling tinggi di Provinsi DI Yogyakarta adalah Kabupaten Sleman $(82,62 \%)$ dan paling rendah terjadi di Kota Yogyakarta $(66,13 \%)$, sedangkan di Kulon Progo sebesar 77\%, Bantul $74,27 \%$, dan terendah keempat Gunung Kidul (66,75\%), hal tersebut berdasarkan data yang dihimpun dari seksi gizi dinas kesehatan Provinsi DI Yogyakarta (Dinas Kesehatan Provinsi DIY, 2018)

Di Indonesia proporsi ibu yang tidak menyusui bayinya dengan alasan ASI tidak keluar sebanyak $65,7 \%$ dan pada kelompok usia $0-6$ bulan yang tidak diberi ASI karena alasan yang sama sejumlah 68,3\% (Balitbankes, 2018). Ketidakberhasilan ASI eksklusif disebabkan oleh produksi ASI yang kurang, hal tersebut terjadi karena ibu berhenti menyusui bayinya. Faktor nutrisi dan hormonal (prolaktin dan oksitosin) merupakan faktor utama yang memengaruhi produksi ASI (Balitbankes, 2018; Iqbal R, dkk, 2017) Prolaktin adalah salah satu hormone yang berperan penting dalam proses laktasi. Prolaktin merupakan hormone utama dalam produksi ASI. Ketika bayi menyusui maka akan merangsang hipotalamus, selanjutnya adenohipofise (hipofisis anterior) akan terangsang sehingga akan mengelurakan prolaktin. Hormon prolaktin ini akan merangsang sel-sel alveoli yang berfungsi untuk membuat ASI (Gimpl,G., Fahrenholz, 2010; Guyton, AC., Hall, 2010; Lawrence,R.M., 2014)

Salah satu cara meningkatkan kadar hormon prolaktin sekaligus adanya peningkatan volume ASI, adalah dengan pemberian galaktagogue (Foong, S.C.,dkk, 2015; Forinash,A.B.,dkk, 2012; Madhavi, N., Manikyamba, 2016). Jantung pisang batu (Musa balbisiana colla) merupakan tanaman mengandung galaktagogue yang mudah ditemui di Indonesia. Jantung pisang batu biasa dinikmati oleh masyarakat dengan cara diolah menjadi sayur bening, urap, atau bahkan tumis. Meskipun begitu manfaat sayuran ini dalam meningkatkan produksi ASI tidak begitu dikenal, berbeda halnya dengan daun katuk, daun kelor, dan daun bangun-bangun yang sudah cukup dikenal dan dikonsumsi oleh ibu menyusui selama masa laktasi. Di Indonesia, jntung pisang batu tidak mendapat perhatiap yng cukup untuk dikembangkan menuju ke arah fitofarmaka, meskipun memiliki potensi yang sangat besar (Wahyuni, E., dkk, 2013; Wahyuningsih, D., dkk, 2017). 
Kandungan senyawa flavonoid, steroid, polifenol, dan tannin terdapat dalam jantung pisang batu yang dalam kondisi segar maupun ekstrak, hal tersebut berdasarkan uji fitokimia yang telah dilakukan oleh peneliti sebelumnya. Aktivitas antioksidan dalam jumlah tinggi yang dimiliki oleh jantung pisang batu sebagian besar berasal dari senyawa antosianin yang termasuk golongan flavonoid sekaligus polifenol. Senyawa flavonoid dan polifenol memiliki potensi untuk menstimulasi hormon prolaktin dan oksitosin sehingga akan terdapat peningkatan produksi ASI (Mahmood, A., dkk, 2011).

Adaptasi fisik dan psikologis ibu nifas perlu diperhatikan bahwa selama nifas kebutuhan asupan zat gizi meningkat. Hal tersebut erat kaitannya dengan ASI yang diproduksi setiap hari. Adaptasi tersebut menyebabkan ibu nifas membutuhkan sebuah asupan nutrisi yang tersedia secara langsung dan mudah dikonsumsi yaitu dalam sediaan teh yang memiliki kandungan nutrisi untuk ibu menyusui.

\section{METODE PENELITIAN}

Desain penelitian ini adalah single blind randomized control trial pretestposttest control group. Penelitian dilakukan selama empat bulan sejak Agustus hingga November 2020. Peneliti melakukan uji formulasi, uji organoleptik, dan uji senyawa antioksidan sebelum intervensi terhadap responden. Jantung pisang batu diperoleh dari daerah Tempel dan Turi, Sleman, Yogyakarta. Pembuatan teh jantung pisang batu dilakukan di laboratorium dietetik dan kuliner Universitas Respati Yogyakarta. Teh untuk kelompok intervensi berisi $100 \%$ jantung pisang batu sementara untuk kelompok kontrol berisi $100 \%$ daun teh (Camellia sinensis) Pengambilan sampel dilakukan secara acak dengan blok permutasi. Sampel pada penelitian ini sebanyak 60 responden (30 kelompok intervensi dan 30 kelompok kontrol), tidak ada responden yang masuk dalam kriteria drop out pada penelitian ini.

Subjek dalam penelitian ini adalah ibu menyusui usia kurang dari 6 bulan di Kabupaten Sleman dan Kota Yogyakarta yang memenuhi kriteria sampel. Kriteria inklusi responden dalam penelitian ini antara lain: ibu primipara dan/atau multipara; ibu yang melahirkan bayi aterm, tunggal, dan sehat; ibu tidak menggunakan obatobatan lain untuk meningkatkan produksi ASI; dan ibu yang bersedia diambil darahnya untuk pemeriksaan prolaktin. Ibu yang memiliki masalah pada payudara, yaitu puting datar/tenggelam dan riwayat operasi pada payudara; ibu yang mengalami komplikasi berat dan memerlukan perawatan; ibu dengan penyakit diabetes melitus dan atau hipertensi; serta ibu yang merokok dan atau minum alkohol akan masuk dalam kriteria eksklusi. Ibu dinyatakan drop out apabila, ibu tidak mengonsumsi teh jantung pisang batu 2 hari berturut-turut atau mengkonsumsi kurang dari dua kantong teh per hari; ibu mengundurkan diri saat intervensi ataupun kontrol diberikan; ibu pindah alamat yang tidak diketahui; ibu mengalami sakit dan memerlukan perawatan; dan bayi diberikan susu formula atau asupan nutrisi selain ASI.

Pemberian teh jantung pisang batu (Musa balbisiana Colla) pada kelompok intervensi sebanyak dua kantong teh/hari (@2,5 gram) selama tujuh hari beturut-turut. Sementara itu pada kelompok kontrol diberi daun teh (Camellia sinensis) dengan jumlah 
konsumsi yang sama setiap harinya selama satu minggu.

Variabel bebas dalam penelitian ini yakni pemberian teh jantung pisang batu, lalu kadar prolaktin serum adalah variabel terikatnya. Pengukuran kadar prolactin dilakukan di hari pertama sebelum intervensi dan hari kedelapan setelah pemberian teh jantung pisang batu di laboratorium patologi klinik RSUD Sleman dan laboratorium Biomedik FK-KMK UGM dengan analisis biokimia darah menggunakan VIDAS. Pengambilan sampel darah dilakukan sekitar pukul 07.00-10.00 pada vena mediana cubiti dengan mengikuti prosedur terstandar, sampling darah dilakukan oleh eumerator dengan basic ahli teknologi laboratorium medik (ATLM) yang memiliki surat tanda registrasi (STR). Data yang dikumpulkan diolah dengan uji non parametrik, yaitu uji Wilcoxon dan uji Mann Whitney karena data tidak berdistribusi nomal. Penelitian ini telah sesuai dengan prinsip-prinsip etik penelitian dan mendapatkan ethical clearance dari Komite Etik Penelitian Kesehatan, Fakultas Ilmu Kesehatan, Universitas Respati Yogyakarta dengan nomor: 157.3/FIKES/PL/VII/2020.

\section{HASIL DAN PEMBAHASAN}

Karakteristik responden responden dilihat berdasarkan usia, status paritas, pendidikan, dan pekerjaan, yang disajikan pada Tabel 1. Pada masing-masing kelompok baik itu intervensi maupun kontrol, sebagian besar responden berusia 20-35 tahun, primipara, dengan pendidikan terakhir SMA, dan tidak bekerja.
Tabel 1. Karakteristik Responden Penelitian

\begin{tabular}{lcccc}
\hline Karakteristik & \multicolumn{2}{c}{ Kelompok intervensi } & \multicolumn{2}{c}{ Kelompok kontrol } \\
\cline { 2 - 5 } & $\mathbf{n}=30$ & $\%$ & $\mathbf{n}=30$ & $\%$ \\
\hline Usia & & & & \\
20 tahun & 6 & 20 & 5 & 16,7 \\
$20-35$ tahun & 17 & 56,7 & 18 & 60 \\
$\quad$ >35 tahun & 7 & 23,3 & 7 & 23,3 \\
Status paritas & & & & \\
$\quad$ Primipara & 19 & 63,3 & 20 & 66,7 \\
$\quad$ Muitipara & 11 & 36,7 & 10 & 33,3 \\
Pendidikan terakhir & & & & \\
SD & 0 & 0 & 0 & 0 \\
SMP & 2 & 6,7 & 2 & 6,7 \\
SMA & 18 & 60 & 21 & 70 \\
PT & 10 & 33,3 & 7 & 23,3 \\
Pekerjaan & & & & \\
$\quad$ Tidak bekerja & 18 & 60 & 20 & 66,7 \\
Bekerja & 12 & 40 & 10 & 33,3 \\
\hline & & & & \\
\hline
\end{tabular}

Hasil analisis statistik menunjukkan ada perbedaan bermakna pada kadar prolaktin serum kelompok intervensi sebelum dengan setelah diberikan perlakuan berupa teh jantung pisang batu, sementara itu pada kelompok kontrol tidak terdapat perbedaan yang signifikan (Tabel 2). Pada kedua kelompok, memiliki peningkatan kadar prolaktin serum setelah diberikan perlakuan yang berbeda. Kelompok intervensi mengalami peningkatan sebesar 30,85\% sementara kelompok kontrol hanya $0,65 \%$. Keduanya terdapat perbedaan yang bermakna signifikan setelah dianalisis berdasarkan uji statistik (Tabel 3).

Tabel 2. Perbandingan Nilai Kadar Prolaktin Serum Kelompok Intervensi dan Kontrol

\begin{tabular}{|c|c|c|c|c|c|c|}
\hline \multirow[t]{2}{*}{ Variabel } & \multicolumn{2}{|c|}{ Intervensi $(\mathrm{n}=30)$} & \multirow[t]{2}{*}{$\mathrm{p}$} & \multicolumn{2}{|c|}{ Kontrol $(\mathrm{n}=30)$} & \multirow{2}{*}{$\mathrm{p}$} \\
\hline & Pretest & Posttest & & Pretest & Posttest & \\
\hline \multirow{2}{*}{\multicolumn{7}{|c|}{$\begin{array}{l}\text { Kadar } \\
\text { Prolaktin }\end{array}$}} \\
\hline & & & & & & \\
\hline $\begin{array}{l}\text { Serum } \\
\text { Median }\end{array}$ & 80,02 & 139,83 & $\begin{array}{c}0,000 \\
*\end{array}$ & 75,81 & 78,39 & $\begin{array}{l}0,766 \\
*\end{array}$ \\
\hline Rentang & $7,02-200$ & $8,13-200$ & & $10,22-200$ & $9,75-198,76$ & \\
\hline $\operatorname{Mean}(\mathrm{S}$ & $94,94(49,46$ & $135,52(45,0$ & & $82,67(40,59$ & $87,41(44,78$ & \\
\hline D) & ) & 5) & & ) & (ind & \\
\hline
\end{tabular}




\section{Tabel 3. Analisis Persen Naik Kadar Prolaktin Serum pada Kelompok Intervensi dan Kontrol}

\begin{tabular}{lccc}
\hline \multicolumn{1}{c}{ Variabel } & $\begin{array}{c}\text { Kelompok Intervensi } \\
\mathrm{n}=30\end{array}$ & $\begin{array}{c}\text { Kelompok Kontrol } \\
\mathrm{n}=30\end{array}$ & $\mathrm{p}$ \\
\hline $\begin{array}{l}\text { Kadar Prolaktin Serum } \\
\text { \% Kenaikan }\end{array}$ & $30,85 \%$ & $0,65 \%$ & $0,000^{*}$ \\
\hline Keterangan: ${ }^{*}$ ) signifikan berdasarkan Uji Mann Whitney & &
\end{tabular}

Pada penelitian ini, sebagian besar responden pada kedua kelompok berstatus primipara. Paritas sedikit banyak memengaruhi sekresi prolaktin. Pada multipara, reseptor di kelenjar susu lebih banyak dimiliki untuk mengikat molekul prolaktin, sehingga selama laktogenesis sirkulasi prolaktin serum berkurang. Perkembangan reseptor di kelenjar susu dapat dirangsang dengan menyusui, kuantitas reseptor meningkat di awal mula masa laktasi selanjutnya akan tetap konstan. Dibanding dengan multipara, konsentrasi serum prolaktin lebih tinggi pada primipara. Usia pun memengaruhi jumlah kadar prolaktin, makin bertambah usia dan mendekati menopause maka kadar prolaktin semakin berkurang (Al-Chalabi, M., Bass, A.N., Alsalman, 2020).

Banyak hal yang memengaruhi produksi ASI, salah satu prediktor untuk mengetahui bagaimana kuantitas produksi ASI adalah kadar prolaktin serum. Pengambilan sampel darah pada responden pukul 07.00-10.00 WIB, hal ini mengacu pada variasi diurnal untuk hormon prolaktin yang banyak terdapat dimalam hari, namun tidak memungkinkan diambil tepat pada malam hari sehingga pagi hari menjadi alternatifnya ketika hormon prolaktin dalam jumlah yang cukup tinggi meskipun tidak setinggi di malam hari (Mostafapour, S., Zare,S., Sadrkhanlou, R.A., Ahmadi, A., \& Razi, 2014).
Prolaktin termasuk hormon polipeptida yang dilakukan sintesis serta sekresi oleh sel laktotrop di hipofisis anterior. Selain itu, prolatin disekresikan juga di limfosit, fibroblas kulit, otak, payudara, desidua, prostat, dan sel adipose, yang terletak di luar hipofisis. Hormon prolaktin merupakan famili somatrotopin, yang secara genetik dan struktural hampir sama dengan human placental lactogen dan growth hormone. Masa laktasi memengaruhi kadar prolaktin serum. Prolaktin yang dilepas, dikontrol oleh dua sekresi hipotalamus antara lain Prolacting Inhibiting Hormone (PIH) dan Prolactin Releasing Hormone (PRH). Prolactin Inhibiting Factor (PIF) melakukan pengendalian pada sekresi prolaktin. Sekresi prolaktin mengalami jumlah yang sedikit pada kondisi normal, karena sebagian besar PIF dilepaskan secara terus menerus ke dalam kelenjar hipofisis anterior. Di sisi lain, pada saat laktasi, penekanan terhadap PIF terjadi, oleh karenanya kelenjar hipofisis anterior melakukan sekresi prolatin dalam kuantitas yang banyak (Hall, 2010).

Hasil penelitian ini menunjukkan bahwa terdapat perbedaan bermakna secara statistik pada kelompok yang mengkonsumsi teh jantung pisang batu (Musa balbisiana Colla) selama tujuh hari berturut-turut dengan dosis dua kali (@2,5 gram) dalam sehari (Tabel 2). Masing-masing kelompok mengalami peningkatan kadar prolaktin serum, namun pada kelompok kontrol lonjakan kenaikannya tidak seperti kelompok intervensi yang sebesar 30,85\%, perbedaan signifikan tersebut pun terlihat antara kedua kelompok (Tabel 3).

Sebuah studi melakukan uji fitokimia pada jantung pisang yang menunjukkan bahwa terdapat 
kandungan alkaloid, saponin, glikosida, tanin, flavonoid, dan steroid. Peningkatan kadar prolaktin serum pada kelompok intervensi disebabkan oleh adanya senyawa tersebut, yang menstimulasi sel sekretori pada kelenjar mammae dan meningkatkan kadar prolaktin untuk memengaruhi sel epitel alveolar sehingga produksi ASI meningkat (Mahmood, A., Ngah, N., Omar, 2011). Pada penelitian lain, ekstrak etanol jantung pisang dapat meningkatkan produksi ASI saat diberikan pada hari ke-5 hingga ke-14 postpartum (Mahmood, A., Omar, M.N., Ngah, 2012).

Mekanisme secara lengkap mengenai peningkatan kadar prolaktin tersebut dijelaskan dalam beberapa studi penelitian, bahwa antioksidan yang bekerja dengan cara menetralkan radikal bebas, dapat mencegah kerusakan oksidatif pada sebagian besar biomolekul dan menghasilkan perlindungan terhadap kerusakan oksidatif secara signifikan. Sintesis senyawa hormon-hormon steroid disebabkan oleh kehadiran senyawa flavonoid, polifenol, saponin, alkaloid, dan glikosida. Hormon steroid beraksi sebagai hasil dari biosintesis senyawa eicosanoid. Hormon tersebut bekerja langsung pada sel-sel sekretoris kelenjar susu dengan cara meningkatkan populasi dan aktivitas sintesisnya. Konsentrasi hormon steroid yang sudah meningkat pada aliran darah, secara tidak langsung menstimulasi sel-sel kelenjar hipofisis anterior dan posterior untuk melepaskan hormon prolaktin dan oksitosin. Kedua hormon tersebut yang kemudian berperan dan terlibat secara langsung dalam sintesis susu dan sekresi ASI (Abdou, R.M., Fathey, 2018; Gupta, M.,Shaw, 2011; Wahyuningsih, D., dkk, 2017).
Jantung pisang batu merupakan salah satu bahan pangan lokal yang mengandung galaktagog (Wahyuni, E., Sumiati, S., Nurliani, 2013). Galaktagog adalah sediaan makanan, herbal, atau bahkan obat yang dipercaya dapat meningkatkan produksi ASI (Foong,S.C., Tan, M.L., Marasco, L.A., Ho, J.J., Foong, 2015). Pada beberapa kasus, konsumsi pharmaceutical galaktagog dalam dosis tinggi dilaporkan dapat meningkatkan risiko artimia, depresi maternal, bahkan hingga kematian mendadak (Paul, C., Zenut, M., Dorut, 2015). Oleh karena adanya efek samping tersebut, tanaman lokal memang dapat menjadi alternatif galaktagog selama masa laktasi (Bazzano, A.N., Hofer,R., Thibeau, S.,Gillispie, V.,Jacobs, 2016).

\section{KESIMPULAN DAN SARAN}

Teh jantung pisang batu memiliki efek galaktagog yang berpotensi meningkatkan produksi ASI. Terdapat perbedaan kadar prolaktin serum secara signifikan antara kelompok yang diberi teh jantung pisang batu (Musa balbisiana Colla) dengan kelompok yang diberikan teh biasa (Camellia sinensis). Ibu yang mengkonsumsi teh jantung pisang batu berturut-turut selama tujuh hari mampu meningkatkan kadar prolaktin serum sebesar $30,85 \%$. Penelitian selanjutnya dapat dilakukan kontrol pada faktor-faktor lain yang memengaruhi kadar prolaktin serum, di antaranya frekuensi dan durasi menyusui.

\section{DAFTAR PUSTAKA}

Abdou,R.M.,Fathey, M. (2018). Evaluation of early postpartum fenugreek supplementation on expressed breast milk volume and prolactin levels variation. Egypt 
Pediatr Assoc Gaz., 66(3), 57-60.

Al-Chalabi,M.,Bass,A.N., Alsalman, I. (n.d.). Physiology, Prolactin. [Updated 2020 Jul 10]. In: StatPearls [Internet]. Treasure Island $\quad(F L)$ : StatPearls Publishing; 2020.Available from: https://www.ncbi.nlm.nih.gov/boo ks/NBK507829/.

Balitbankes. (2018). Riset kesehatan dasar 2018.

Bazzano,A.N.,Hofer,R., Thibeau,S.,Gilli spie,V.,Jacobs, M. e. al. (2016). A review of herbal and pharmaceutical galactagogues for breast-feeding. Ochsner J., 16(4), 511-524.

BPPSDM RI. (2012). Survei Demografi dan Kesehatan Indonesia (SDKI) 2012.

Dinas Kesehatan Provinsi DIY. (2018). Profil Kesehatan DIY 2017.

Foong, S.C., Tan, M.L., Marasco, L.A., Ho,J.J.,Foong, W. . (2015). Oral galactagogues for increasing breast-milk production in mothers of non-hospitalised term infants. Cochrane Database Syst Rev, 14.

Forinash,A.B., $\quad$ Yancey,A.M., Barnes,K.N., Myles, T. . (2012). The use of galactogogues in the breastfeeding mother. Ann Pharmacoter, 46, 1392-1404.

Gimpl,G., Fahrenholz, F. (2010). The Oxytocin Receptor System: Structure, Function, And Regulation, 81(2), 629-683.

Gupta, M., Shaw, B. (2011). A doubleblind randomized clinical trial for evaluation of galactogogue activity of asparagus racemosus willd. Iran J Pharm Res, 10(1), 167-172.
Guyton, AC., Hall, J. (n.d.). Textbook of Medical Physiology. 11th Ed. Philadelphia, PA, USA: Elsevier Saunders.

Hall, J. E. (2010). Guyton and Hall textbook of medical physiology, Elsevier Health Sciences.

Iqbal,R.,Ali,M.,Amin,M.,Saleem,M.,An wer,J.,Ali, S. (2017). Factors involved in failure of exclusive breastfeeding practices among mothers. JSZMC, 8(1), 11131116.

Kemenkes RI. (2018). Profil Kesehatan Indonesia 2018.

Lawrence, R. M., \& L. R. A. (2014). Creasy And Resnik's MaternalFetal Medicine principles And Practice. 7th Ed. Elsevier Inc.

Madhavi, N., Manikyamba, D. (2016). Evaluation of factors responsible for failure of exclusive breastfeeding for first 6 months hospital based study. Int $J$ Contemp Med Research, 3(6), 1701-1704.

Mahmood,A., Omar, M.N., Ngah, N. (2012). Galactagogue effects of Musa x paradisiaca flower extract on lactating rats. Asian Pacific Journal of Tropical Medicine, 882-886.

Mahmood,A.,Ngah,N.,Omar, M. N. (2011). Phytochemicals constituent and antioxidant activities in Musa x Paradisiaca flower. Eur J Sci Res, 66, 311318.

Mostafapour, S., Zare, S., Sadrkhanlou, R. A., Ahmadi, A., \& Razi, M. (2014). Sulpiride-induced hyperprolactinemia in mature female rats: evidence for alterations in the reproductive system, pituitary and ovarian 
hormones. International Journal of Fertility \& Sterility, 8(2), 193206.

Paul,C., Zenut,M.,Dorut, A. (2015). Use of domperidone as a galactagogue drug: a systematic review of the benefit-risk ratio. ,. J Hum Lact., 31(1), 57-63.

UNICEF. (2010). Improving Exclusive Breast Feeding Practices by using Communication for Development in Infant and young Child Feeding Programs.

Wahyuni,E.,Sumiati,S.,Nurliani, N. (2013). Pengaruh konsumsi jantung pisang batu terhadap peningkatan produksi ASI di Wilayah Puskesmas Srikuncoro, Kecamatan Pondok Kelapa, Bengkulu Tengah Tahun 2012. Bul Penelit Sist Kesehat., 15.

Wahyuningsih,D.,Hidayat,S.T.,Khafidh oh,N.,Suwondo,A.,Fatmasari,D.,S usiloretn, K. A. (2017). Effect of Musa balbisiana colla extract on breastfeeding. $J$ Gizi Pangan, 3(3), 174-182. 